\title{
Latitudinal variation in the reproductive cycle of two bivalves with contrasting biogeographical origin along the Humboldt Current Upwelling Ecosystem
}

\author{
ROBERTO A. URIBE ${ }^{1}$, MARCELO E. OLIVA ${ }^{2}$, SILVIA AGUILAR ${ }^{3}$, \\ CARMEN YAMASHIRO ${ }^{3}$ and JOSÉ M. RIASCOS ${ }^{2}$ \\ ${ }^{1}$ Programa de Doctorado en Ciencias Aplicadas Mención Sistemas Marinos Costeros, Universidad de Antofagasta, \\ Avenida Angamos 601, Antofagasta, Chile. E-mail: uribealzamora@gmail.com \\ ${ }^{2}$ Instituto de Investigaciones Oceanológicas, Universidad de Antofagasta, Avenida Angamos 601, Antofagasta, Chile. \\ ${ }^{3}$ Instituto del Mar del Perú, Esq. Gamarra y Gral. Valle s/n, La Punta, Callao, Perú. E-mail: scallops2@ hotmail.com
}

SUMMARY: Argopecten purpuratus (Lamarck, 1819) and Mesodesma donacium (Lamarck, 1818) are bivalves that inhabit the Humboldt Current Upwelling Ecosystem. They have contrasting biogeographical origins, suggesting that their responses to exogenous factors should differ. Using circular statistics, we examine synchrony/asynchrony in the reproductive cycle between populations of each species. The results indicate that there is reproductive asynchrony in both species along their distributional range. However, there was synchrony for A. purpuratus in several location-pairs, including Paita-Chimbote, Chimbote-Callao, Callao-Pisco and Pisco-Antofagasta. For M. donacium, there were only two synchronic groups: CamanáCapellanía-Mehuín and Hornitos-Peñuelas-Longotoma-La Ligua-Cucao-Quilanlar. A. purpuratus showed gametogenenic activity throughout the year. In contrast, $M$. donacium showed strong seasonality, with gametogenesis in winter and spawning in spring/summer. In conclusion, the patterns observed for these sympatric species suggest that on a large scale the reproductive cycles follow the expected patterns for the contrasting biogeographic origin of each species, so it could be argued that they are modulated by endogenous factors. However, at a local scale, the reproductive cycles of these species show variation, likely determined by local oceanographic or hydrographic processes.

Keywords: Mesodesma donacium, Argopecten purpuratus, synchronic reproduction, gametogenesis, exogenous factors, circular statistics.

RESUMEN: VARIACIÓN LATITUdINAL DEL CICLO REPRODUCTIVO DE DOS BIVALVOS CON ORÍGENES BIOGEOGRÁFICOS CONTRASTANTES A LO LARGO DEL ECOSISTEMA DE AFLORAMIENTO DE LA CORRIENTE DE HumboldT. - Argopecten purpuratus (Lamarck, 1819) y Mesodesma donacium (Lamarck, 1818) son moluscos bivalvos endémicos del sistema de afloramiento de la Corriente de Humboldt pero tienen orígenes biogeográficos opuestos. Por tanto, se esperaría que los factores exógenos afectaran sus ritmos biológicos diferencialmente, entre ellos sus ciclos reproductivos. Mediante análisis de distribución circular se evaluó el sincronismo/asincronismo en ciclos reproductivos entre poblaciones de cada especie. Los resultados indican que existe asincronía reproductiva en ambas especies a lo largo de su distribución. Sin embargo para A. purpuratus se encontró varios pares de localidades sincrónicas: Paita-Chimbote; Chimbote-Callao; Callao-Pisco y Pisco-Antofagasta, y para M. donacium se dieron dos grupos sincrónicos, el primero entre las poblaciones de Camaná, Capellanía y Mehuín; y el segundo grupo entre Hornitos, Peñuelas, Longotoma, La Ligua, Cucao y Quilanlar. A. purpuratus presentó actividad gametogénica continua. En contraste, $M$. donacium presentó una marcada estacionalidad, con gametogénesis durante invierno y desoves durante primavera y/o verano. En conclusión, los patrones observados para ambas especies simpátricas sugieren que, a gran escala el ciclo reproductivo sigue los patrones esperados para el origen biogeográfico contrastante de cada especie, por lo tanto se podría argumentar que es modulada por factores endógenos. Sin embargo, a escala local el ciclo reproductivo de ambas especies muestra variaciones, aparentemente influenciados por los factores oceanográficos o hidrográficos locales.

Palabras clave: Mesodesma donacium, Argopecten purpuratus, sincronismo reproductivo, gametogénesis, factores exógenos, distribución circular. 


\section{INTRODUCTION}

The Humboldt Current Upwelling Ecosystem (HCUE) comprises several oceanic and coastal currents and influences a wide part of the west coast of South America, from southern Chile $\left(45^{\circ} \mathrm{S}\right)$, up to northern Peru and Ecuador ( $\left.4^{\circ} \mathrm{S}\right)$ (Strub et al. 1998). The current configuration of the system probably originated when the bridge between South America and Antarctica broke during the Oligocene (about 29-23 Ma) (Camus 2001), thus connecting the Pacific and the Atlantic Oceans. The resulting Circumpolar Antarctic current impacts the southern coast of Chile, thus forming two currents: the eastward Cape Horn current and the northward Humboldt Current (Camus 2001). The latter, when mixing with the Equatorial Countercurrent, forms the HCUE. One of the main features of the system is that sea surface temperature is $5^{\circ} \mathrm{C}$ to $10^{\circ} \mathrm{C}$ colder than that of other coastal systems at the same latitude (Urban 1994, Montecino and Lange 2009). In the HCUE there are frequent upwelling events that vary in intensity all along the coast. Upwelling is less active in northern-central Chile and more intense and continuous in centralnorthern Peru (Thiel et al. 2007).

The prevalent physical conditions in the HCUE determine the spatial characteristics of three biogeographic units: (1) the Peruvian province, dominated by subtropical and temperate species with affinities to warm-temperate waters, extending from northern Peru (4-6 $\left.{ }^{\circ} S\right)$ to northern Chile with species-specific variations; (2) the Magellanic province dominated by sub-Antarctic and temperate species with affinities to cold-temperate waters, extending from southern Chile $\left(54^{\circ} \mathrm{S}\right)$ to $41-43^{\circ} \mathrm{S}$; and, (3) a transition zone between these two provinces, characterized by a strong reduction of subtropical and sub-Antarctic species at the southern and northern borders, respectively (Thiel et al. 2007). As a result, several marine invertebrates of different biogeographic origins are distributed sympatrically over large regions of these biogeographical units. Hence, the question arises whether the life-history traits and biological rhythms of this mixed fauna are defined as a common response to the prevalent physical conditions or reflect their distinct respective origins, as suggested by Carstensen et al. (2010).

In marine invertebrates, the reproductive cycle is defined as a cyclic group of events that start with gonad activation, gametogenesis, maturity and spawning, and end with recession (Vance 1973). The cycle can be divided into two phases: an active phase linking the onset of gametogenesis until spawning, and a passive phase, which includes a resting stage, where residual gametes are re-absorbed and reservoir substances are stored (Vance 1973, Gurney and Mundy 2004). In bivalve molluscs, the reproductive cycle can be regulated exogenously by environmental factors such as temperature, salinity, light intensity, lunar cycle and food availability (Giese 1959, Stead et al. 2002). However, endocrine activity plays an important role in the gametogenic cycle of bivalves (Barber and Blake 2006, Ketata et al. 2007, Kang et al. 2009). Though less is known regarding the internal factors regulating reproductive processes, bivalves are structural, functional and self-regulated systems showing adaptation mechanisms towards the signals coming from external or internal sources (Ketata et al. 2007, Martínez 2008).

From a biogeographic perspective, species thriving at high latitudes have reproductive cycles characterized by short spawning periods during warm seasons, whereas at low latitudes spawning periods are longer and can occur throughout the year (Giese 1959). Based on this conceptual viewpoint, we compared the reproductive cycle of two commercially-important species with opposite biogeographic origins and wide distribution ranges along the HCUE. The bay scallop A. purpuratus is a functional hermaphrodite of tropical origin and is distributed from Paita $\left(5^{\circ} 04^{\prime} S\right)$, Peru to Bahía San Vicente, in southern Chile $\left(37^{\circ} \mathrm{S}\right.$ ) (Wolff and Mendo 2000). This species inhabits shallow waters (between 5 and $30 \mathrm{~m}$ depth) (Avendaño and Cantillánez 2005) and is eurythermal. It is considered a biogeographical relict of the subtropical fauna before the establishment of the HCUE (Wolff 1987). This is also reflected in the demographic explosions during warm El Niño events, particularly in Peruvian populations (Wolff 1987). Currently, natural populations have declined due to changes in predator populations and overexploitation (Thiel et al. 2007). The surf clam M. donacium is a gonocoric bivalve of Antarctic origin and is distributed from Paita, Peru ( $\left.5^{\circ} 04^{\prime} S\right)$ to the island of Chiloé in Chile (4320'S) (Tarifeño 1980). However, the combined effects of strong El Niño events and intense fishing pressure have caused local extinctions of the populations at the northern biogeographical limit (Riascos et al. 2011a, b). The present distribution is currently restricted from Camaná in southern Peru to Chiloé (Barriga and Quiroz 2002, Carré et al. 2005a, Riascos et al. 2009). This species inhabits sandy beaches with strong wave exposure from the low intertidal down to 15 to $20 \mathrm{~m}$ depth. It is stenothermic and its low tolerance to high temperatures is presumably attributed to its biogeographical origin. M. donacium is found in South America due to a massive migration of Antarctic species during the late Miocene and early Pleistocene. The development of an Oxygen Minimum Zone and high productivity associated with low temperatures in the HCUE allowed this species to extend its geographic distribution along the three biogeographic units of the South American coast (Guzmán et al. 2000, Riascos et al. 2009).

In this context, it is important to establish the temporal features of the biological cycles of endemic species in the HCUE. This requires analysis of historical data that cover the wide spatial scale in which these species occur. Here, the synchrony/asynchrony of the active phase of the reproductive cycle of $A$. purpuratus 


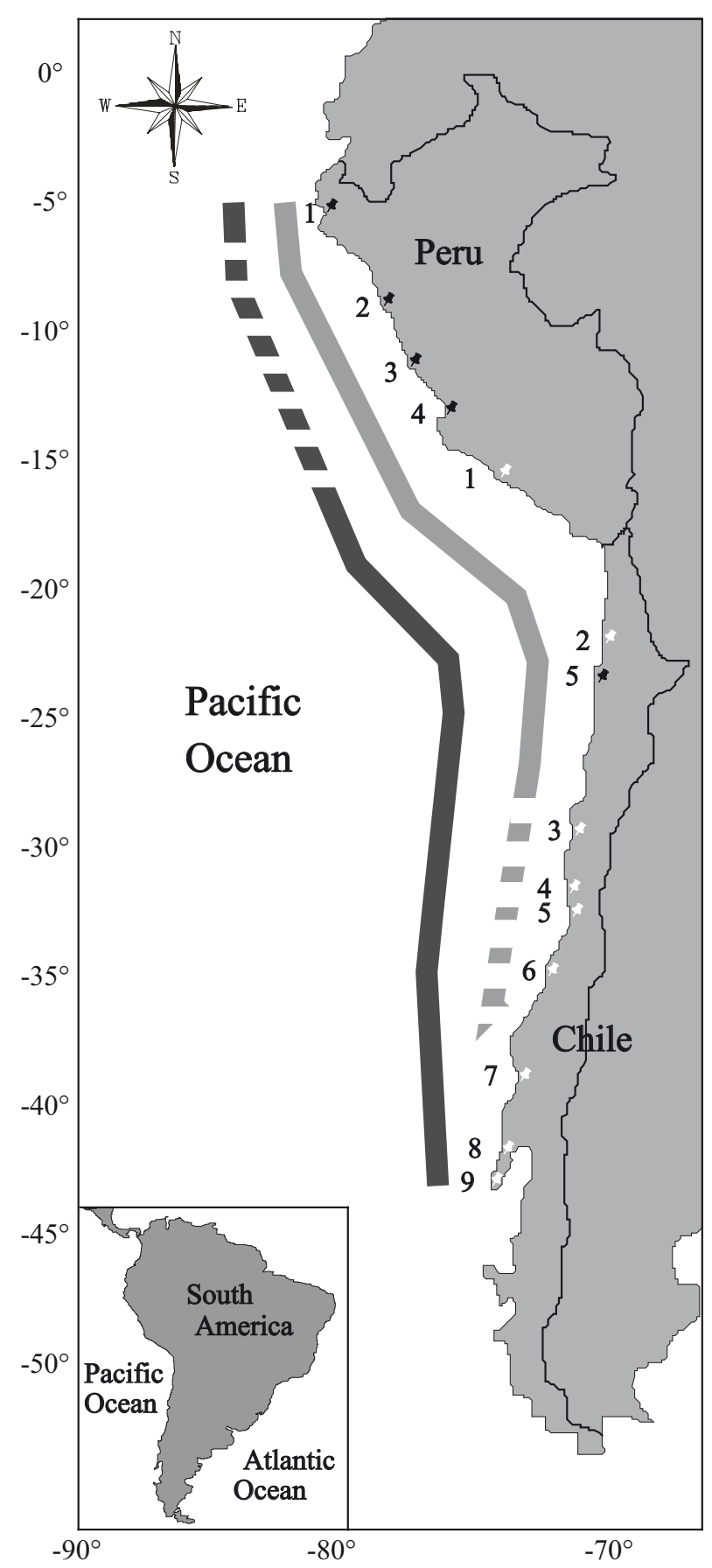

FIG. 1. - Map of South America showing the local populations of the species included in this study and their distribution range. White symbols, $M$. donacium; localities: 1 , Camaná; 2 , Hornitos; 3 , Peñuelas; 4, Longotoma; 5, La Ligua; 6, Capellanía; 7, Mehuín; 8, Cucao; 9, Quilanlar. Black symbols, A. purpuratus; localities: 1, Paita; 2, Chimbote; 3, Callao; 4, Pisco; 5, Antofagasta. Dark grey line, $A$. purpuratus. Grey line, M. donacium. Bold sector lines indicate the current distribution, while dotted sector lines show the historical distribution.

and $M$. donacium were assessed along their geographical distributional range in order to characterize the species-specific responses to the prevalent environmental conditions in the HCUE.

\section{MATERIALS AND METHODS}

\section{Data sources}

A database was generated using information about the reproductive cycle of the two species from several locations covering most of the geographic distribution (Fig. 1). This information consisted of gonad stage classifications based on histological sections obtained by standard techniques. Each study was based on monthly samples covering at least one year. For $A$. purpuratus the information collected covered the area between Paita, Peru and Antofagasta, Chile (Fig. 1). For M. donacium, information from Camaná, Peru to Quilanlar, Chile (Fig. 1) was used. Studies conducted during El Niño events were excluded as these events affect spatial and temporal patterns of the reproductive cycle of bivalves (e.g. Peredo et al. 1987, Urban and Tarazona 1996, Riascos et al. 2008). Information on $A$. purpuratus in Paita, Chimbote, Callao and Pisco was obtained from the Instituto del Mar del Perú (IMA$\mathrm{RPE})$, complemented with an extensive literature review. For $M$. donacium we used the database provided in Riascos et al. 2009 for several locations in Peru and Chile, complemented by an extensive literature review (Table 1).

\section{Standardization}

Because the classification of histological gonadal stages differed among publications, five stages of gonadal development for male and female of both species (Table 2) were standardized: (I) immature, (II) maturing, (III) spawning, (IV) spawned and (V) recovering. For descriptive purposes, maturing and spawning stages were considered as the active phase of the cycle, and spawned and recovering as the passive phase. These standardization levels were used to describe the variability along the geographic distribution.

\section{Statistical analyses}

Several biological phenomena occur on a circular scale (e.g. diel, tidal, annual), in which there is no true zero point and any designation of high or low values is arbitrary. Although these phenomena require the use of circular statistics (Batschelet 1981), this is rarely described in the literature. In this study, circular statistics (Zar 1999) were used to evaluate the occurrence of synchrony during the active phase of reproduction along the distributional range of each species. Briefly, monthly values were transformed to degrees, changing monthly frequency distribution (i.e. January to December) into a circular distribution, through which comparative results can be obtained from data collected in any month. The analysis of data distributed on a circular scale takes into account the monthly direction in degrees, so there are no limitations due to the different starting months reported in the studies reviewed here. 
716 - R.A. URIBE et al.

TABLE 1. - Circular summary statistical for each locality. Total sampling months $(\mathrm{N})$, mean direction $(\overline{\mathrm{a}})$, mean resultant length (R), circular variance $(\mathrm{V})$ and standard deviation $(\mathrm{v})$.

\begin{tabular}{|c|c|c|c|c|c|c|c|}
\hline Species & Localities & Coordinates $(\mathrm{S})$ & $\mathrm{N}$ & $\overline{\mathrm{a}}$ & $\mathrm{R}$ & $\mathrm{V}$ & $\mathrm{v}$ \\
\hline \multirow[t]{9}{*}{ Mesodesma donacium } & Camaná & $16^{\circ} 36^{\prime}$ & 12 & 311.28 & 0.64 & 0.36 & 54.13 \\
\hline & Hornitos & $22^{\circ} 54^{\prime}$ & 24 & 0.70 & 0.56 & 0.44 & 61.30 \\
\hline & Peñuelas & $29^{\circ} 50^{\prime}$ & 14 & 35.89 & 0.43 & 0.57 & 74.71 \\
\hline & Longotoma & $32^{\circ} 22^{\prime}$ & 14 & 6.27 & 0.82 & 0.18 & 35.89 \\
\hline & La Ligua & $32^{\circ} 22^{\prime}$ & 16 & 10.33 & 0.90 & 0.10 & 25.62 \\
\hline & Capellanía & $35^{\circ} 15^{\prime}$ & 12 & 301.29 & 0.50 & 0.50 & 67.71 \\
\hline & Mehuín & $39^{\circ} 26^{\prime}$ & 24 & 354.38 & 0.66 & 0.34 & 51.82 \\
\hline & Cucao & $42^{\circ} 35^{\prime}$ & 12 & 38.65 & 0.46 & 0.54 & 71.58 \\
\hline & Quilanlar & $43^{\circ} 23^{\prime}$ & 12 & 19.09 & 0.99 & 0.01 & 9.18 \\
\hline \multirow[t]{5}{*}{ Argopecten purpuratus } & Paita & $5^{\circ} 04^{\prime}$ & 12 & 325.31 & 0.80 & 0.20 & 38.04 \\
\hline & Chimbote & $9^{\circ} 08^{\prime}$ & 12 & 326.27 & 0.92 & 0.08 & 23.67 \\
\hline & Callao & $12^{\circ} 07^{\prime}$ & 12 & 349.05 & 0.99 & 0.01 & 7.86 \\
\hline & Pisco & $13^{\circ} 48^{\prime}$ & 12 & 355.77 & 0.93 & 0.07 & 25.56 \\
\hline & Antofagasta & $23^{\circ} 38^{\prime}$ & 12 & 319.06 & 0.53 & 0.47 & 64.82 \\
\hline
\end{tabular}

TABLE 2. - Standardized stages of the reproductive cycle of $M$. donacium and A. purpuratus taken from different sources and different localities.

\begin{tabular}{|c|c|c|}
\hline Stages standardized & Mesodesma donacium & Argopecten purpuratus \\
\hline I Immature & $\begin{array}{l}\text { Initiation of maturation (Jerez et al. 2011) } \\
\text { Initiation of maturation (Rubilar et al. 2011) } \\
\text { Immature and initiation of maturation } \\
\quad \text { (Salgado and Ishiyama 2011) } \\
\text { Immature (Tarifeño 1980) } \\
\text { Immature (Filun 2011) } \\
\text { Pre-active (Riascos et al. 2011b) }\end{array}$ & $\begin{array}{l}\text { Immature (De la Cruz et al. 2006) } \\
\text { Initiation of maturation (Cantillánez et al. 2005) } \\
\text { Initiation of maturation (Fiestas et al. 2009) }\end{array}$ \\
\hline II Maturing & $\begin{array}{l}\text { Developing and ripe (Tarifeño 1980) } \\
\text { Later maturation (Rubilar et al. 2011) } \\
\text { Maturation (Jerez et al. 2011) } \\
\text { Mean mature and mature (Salgado and Ishiyama 2011) } \\
\text { Maturing and ripe (Filun 2011) } \\
\text { Later maturation (Jerez et al. 2008) }\end{array}$ & $\begin{array}{l}\text { Maturation (De la Cruz et al. 2006) } \\
\text { Mean mature (Fiestas et al. 2009) } \\
\text { Maturation (Cantillánez et al. 2005) } \\
\text { Advanced maturity and atresia (Cantillánez et al. 2005) }\end{array}$ \\
\hline III Spawning & $\begin{array}{l}\text { Releasing gametes (Rubilar et al. 2011) } \\
\text { Releasing gametes (Rubilar et al. 2011) } \\
\text { Early spawning and spawned } \\
\text { (Salgado and Ishiyama 2011) } \\
\text { Active (Riascos } \text { et al. 2011a) }\end{array}$ & $\begin{array}{l}\text { Spawning (De la Cruz et al. 2006) } \\
\text { Releasing gametes (Cantillánez et al. 2005) } \\
\text { Releasing gametes (Fiestas } \text { et al. 2009) }\end{array}$ \\
\hline IV Spawned & $\begin{array}{l}\text { Spawned (Jerez et al. 2011) } \\
\text { Spawned (Tarifeño 1980) } \\
\text { Spawned (Rubilar } \text { et al. 2011) } \\
\text { Spawned (Riascos } \text { et al. 2011a) } \\
\text { Spawned (Filun 2011) }\end{array}$ & $\begin{array}{l}\text { Spawned (De la Cruz et al. 2006) } \\
\text { Spawned (Fiestas et al. 2009) } \\
\text { Quiescence (Cantillánez et al. 2005) }\end{array}$ \\
\hline V Recovering & $\begin{array}{l}\text { Quiescence (Salgado and Ishiyama 2011) } \\
\text { Recovering (Tarifeño 1980) } \\
\text { Recovering (Filun 2011) } \\
\text { Cytholysed (Riascos } \text { et al. 2011a) }\end{array}$ & Recovering (De la Cruz et al. 2006) \\
\hline
\end{tabular}

To determine whether the active reproductive phase occurred synchronically along the distributional range, data were converted into a circular scale with direction, and a Watson-William multiple angular-sample test was then applied. This parametric test assumes that each of the annual cycles consists of data with uniform distribution surrounding a circle. The data are transformed to degrees to compare the angle direction of each reproductive cycle among localities (Zar 1999):

$$
\overline{\mathrm{a}}=\left(360^{\circ}\right)(X) / k
$$

where $X$ are monthly values for which an angular di- rection ( $\overline{\mathrm{a}}$, in degrees) was calculated and $k$ is the total expression of the complete cycle. Values for gonad development stages in the active phase for each location are expressed in percentage; the $k$-value is thus 100. As in the classic analysis of variance, here an $F$-value is estimated and contrasted with a critical $\mathrm{F}$ $(P>0.05)$. For this analysis a circular variance $(\mathrm{V})$, a central tendency measurement ( $\bar{a} ;$ middle angle) and a data dispersion measurement $(\mathrm{R}$, mean resultant length, which ranges from 0 to 1 with 0 as the minimum dispersion and 1 the maximum dispersion) were calculated. 


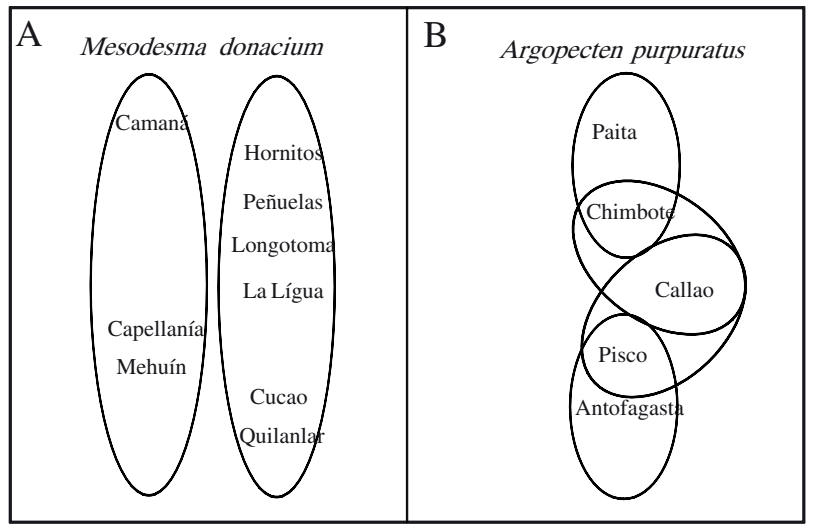

FIG. 2. - Graphic representation of the Watson-Williams test for synchrony among localities. Synchronic groups are denoted by circles. A, Mesodesma donacium; B, Argopecten purpuratus.

\section{RESULTS}

The analysis of synchrony in the reproductive cycle showed that A. purpuratus was characterized by a continuous active phase in all localities (Table 1). Nonetheless, several pairs of localities were synchronic: Paita-Chimbote; Chimbote-Callao; CallaoPisco and Pisco-Antofagasta (Fig. 2). Even though the active phase was continuous for all localities, a gradual increment in the frequency of the passive phase was observed towards higher latitudes (Fig. 3 ), with the Antofagasta population showing higher dispersion.

M. donacium showed two groups of localities with similar middle angles (ā) (Table 1). The first group contained the populations at Camaná, Mehuín and Capellanía, showing synchronic reproduction during the entire year and a short passive phase period, partially for the Camaná population and almost totally for the populations in Capellanía and Mehuín (Fig. 2 and 3 ). The second group included populations from Hornitos, Peñuelas, Longotoma, La Ligua, Cucao and Quilanlar, with an active phase in seasonal synchrony and the passive phase during most of the year (Fig. 2). Populations in Longotoma, La Lígua and Quilanlar showed a longer seasonal active phase with short lags during the months of higher frequency of the active phase (Fig. 3). Peñuelas and Longotoma showed a longer active phase than La Ligua, Cucao and Quilanlar (Fig. 3).

\section{DISCUSSION}

A. purpuratus and $M$. donacium showed different reproductive cycles, with continuous and seasonal cycles of gametogenic activity, respectively. This marked contrast in the reproductive cycle of two species thriving across an approximately similar latitudinal range implies that the physical conditions in the HCUE affect these organisms differently. It is clear that latitude per se does not affect this particular aspect of the biology of these organisms. Are the physical conditions that vary with latitude (i.e. temperature, photoperiod), which may act as exogenous factors, influencing or controlling the reproductive processes of different species in different ways?

The active phase of the reproductive cycle of $A$. purpuratus is continuous throughout the year, reflecting the general pattern observed for tropical species or those with tropical affinity (e.g. Urban 2001, Avendaño et al. 2008). A progressive decrease of the active phase
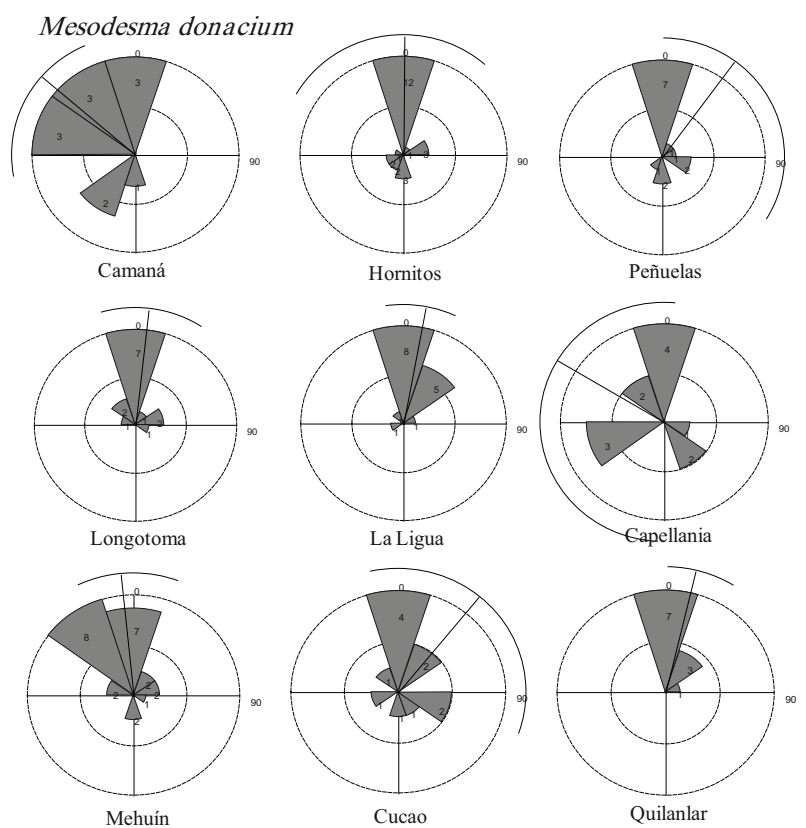

Argopecten purpuratus
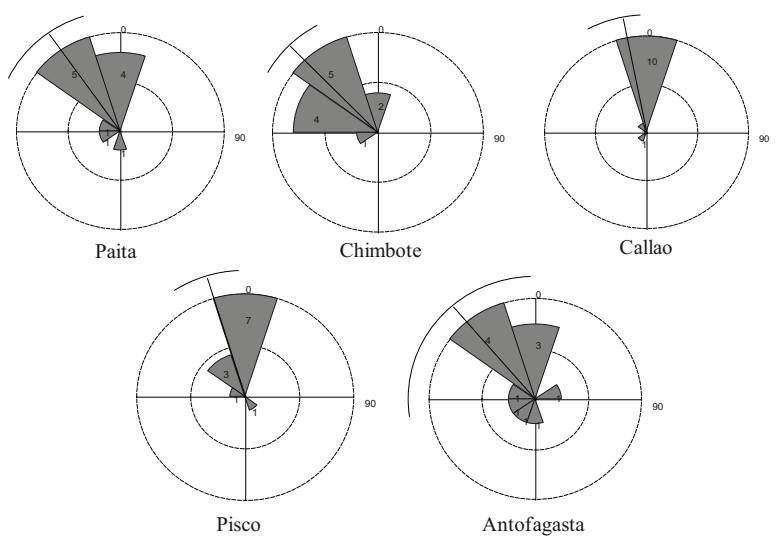

FIG. 3. - Circular representation of the gonadal stage frequency in the active phase per locality and index of dispersion and central tendency for the statistical test. Shadowed areas and numbers represent the frequency expressed in degrees. The line crossing the circle represents the middle angle $(\bar{a})$. The line outside the circle represents the variance $(\mathrm{V})$. 
during the winter in the populations located south of Callao was observed, most markedly in Antofagasta (Cantillánez et al. 2005, Avendaño et al. 2008). This implies that the reproductive cycle in this scallop is influenced by the temperature latitudinal gradient in the HCUE. Though A. purpuratus is well adapted to the general cold conditions of this system, the low temperatures south of Callao apparently limit gametogenic activity.

Several studies have suggested that the continuous gametogenic activity in $A$. purpuratus is a strategy of adaptation to the combination of environmental conditions, especially temperature and food availability (Illanes et al. 1985, Wolff 1988, Cantillánez et al. 2005, Avendaño et al. 2008). A small seasonal increase in river inflow seems to disturb the gametogenic activity of $A$. purpuratus as seen in Paita (Taylor et al. 2008). Low temperatures at the southern limit of the distributional range may limit the gametogenic activity to a shorter season. The variability of food availability linked to the decreasing intensity and increasing seasonality of the upwelling process at higher latitudes along the HCUE (Riascos et al. 2009) seem to be related to the gametogenic activity of this species. As such populations at Chimbote, Callao and Pisco are influenced by continuous and intense centres of upwelling (Montecino \& Lange 2009), which results in a high availability of food e.g. for filter-feeding molluscs. However, the decreased food availability associated with El Niño does not seem to affect local populations of $A$. purpuratus, which display increased reproductive activity and recruitment and colonization toward southern latitudes (Wolff 1987, Tarazona et al. 2007). Therefore, temperature rather than food availability may limit the reproductive activity in southern populations.

Southern populations of $A$. purpuratus can persist during strong El Niño events as relict populations in protected areas, where local environmental conditions are suitable to maintain viable populations (Wolff 1987). This appears to be the case of the population in Antofagasta Bay, where the local oceanographic setting promotes circulation and retention of water masses of higher temperature and higher phytoplankton concentration (Piñones et al. 2007). Under these local conditions, A. purpuratus display continuous gametogenic activity (Avendaño et al. 2008), resembling populations further north.

M. donacium populations showed clear seasonal patterns in their reproductive cycles, as observed for the closely related species $M$. mactroides in some locations of the Atlantic coast (Herrmann et al. 2009). At a local scale, previous studies have indicated that factors such as temperature, precipitation, salinity, upwelling and river discharge can regulate reproductive cycle in specific localities (Tarifeño 2008, Rias$\cos$ et al. 2009). Seasonal and spatial variability of river discharge and precipitation have a particularly strong influence on the reproductive cycle in some locations (Riascos et al. 2009). In the present study, the populations at Camaná, Capellanía and Mehuín showed synchrony during a large part of the year. This finding could be related to the influence of nutrient discharge and sediment load from the rivers Camaná (Camaná), Huenchullami (Capellanía) and Lingue (Meuhin), in contrast to the other locations (Hornitos, Peñuelas, Longotoma, La Lígua, Cucao and Quilanlar), where seasonal variation of the upwelling (north) and coastal precipitation (south) would be greater. According to Thiel et al. (2007), gonadal production in several carnivorous and suspension-feeding molluscs varied along a latitudinal gradient of the HCUE. This was related to the distance of the study sites to upwelling centres, thus suggesting that small-scale variation in environmental conditions seems to affect gonad production.

Paleoecological evidence suggests that $M$. donacium has an Antarctic origin (von Ihering 1907, Marins and Levy 1999) and its expansion and dominance towards the north has been linked to the establishment of cold conditions and the prevalent northward current flow, as seen in other species in the system (Riascos et al. 2009). We hypothesize that the original stock of $M$. donacium was adapted to cold and estuarine conditions where river discharge and ice melting seasonal cycles modulated food availability and thus acted as external controllers of the reproductive cycle. With the establishment of the HCUE, the colonization of the northern desert coast implied the association of the population with river discharge or upwelling influence in the regulation of the food availability and therefore the biological rhythms. Owing to a limited tolerance to high temperatures, the colonization of northern locations and thus the northern distributional range fluctuate with the thermal variability associated with the El Niño/La Niña cycle (Carré et al. 2005b, Riascos et al. 2009).

A circular statistical approach was used here to compare the temporal features of reproductive cycles among populations. Commonly, comparisons and descriptions of reproductive cycles are based on visual assessments of temporal changes in gonadal stages (e.g. González et al. 2002, Cantillánez et al. 2005, Oyarzún et al. 2010). The approach used here can be extended to integrate different data sets, statistically test ecological hypotheses regarding the reproductive cycle of different subpopulations, and identify the environmental factors affecting them. In conclusion, the patterns observed for these sympatric species suggest that on a large scale, the reproductive cycles followed the predicted patterns, reflecting the different biogeographic origin of each species, and hence it could be argued that they are modulated by endogenous factors. However, at a local scale, the reproductive cycles of these species show variation around a general pattern that seemingly reflects local oceanographic or hydrographic processes that promote local rhythms in reproductive activity. 


\section{ACKNOWLEDGEMENTS}

This study was supported by the Programa MECE 2 Educación Superior/MECESUP (Chile), project MECE ANT0711. We thank Chris Harrod for English editing on the manuscript.

\section{REFERENCES}

Avendaño M., Cantillanes M., Thouzeau G., Le Pennec M. 2008. Reproductive and larval cycle of the scallop Argopecten purpuratus (Ostreoida: Pectinidae), during El Niño-La Niña events and normal weather conditions in Antofagasta, Chile. Rev. Biol. Trop. 56: 121-132.

Avendaño M., Cantillánez M. 2005. Growth and demographic structure of Argopecten purpuratus (Lamarck, 1819), in the La Rinconada Marine Reserve, Antofagasta, Chile. Cienc. Mar. 31: 491-503.

Barber B., Blake N. 2006. Reproductive physiology. In: Shumway S.E., Parsons G.J. (eds.), Scallops: Biology Ecology and Aquaculture. Developments in Aquaculture and Fisheries Science pp. 357-416.

Barriga E., Quiroz M. 2002. Impacts of El Niño and La Niña events on the populations of clam (Mesodesma donacium, Lamarck 1818) along the southern Peruvian coast. Invest. Mar. 30: 134-135.

Batschelet E. 1981. Circular Statistics in Biology. Academic Press, London, $371 \mathrm{pp}$

Camus P.A. 2001. Biogeografía marina de Chile continental. Rev. Chil. Hist. Nat. 74: 587-617.

Cantillánez M., Avendaño M., Thouzeau G., Le Pennec M. 2005. Reproductive cycle of Argopecten purpuratus (Bivalvia: Pectinidae) in la Rinconada marine reserve, (Antofagasta, Chile) response to environmental effects of El Niño and La Niña. Aquaculture 246: 181-195

Carré M., Benthaleb I., Blamart D., Ogle N., Cardenas F., Zeballos S., Kalin R., Ortlieb L., Fontugne M. 2005a. Stable isotopes and sclerochronology of the bivalve Mesodesma donacium: potential application to Peruvian paleoceanographic reconstructions. Palaeogeogr. Palaeoclimatol. Palaeoecol. 228: 4-25.

Carré M., Bentaleb I., Fontugne M., Lavallée D. 2005b. Strong El Niño events during the early Holocene: stable isotope evidence from Peruvian sea-shells. The Holocene 15: 42-47.

Carstensen D., Riascos J., Heilmayer O., Arntz E., Laudien J. 2010. Recurrent, thermally-induced shifts in species distribution range in the Humboldt Current upwelling system. Mar. Environ. Res. 70: 293-299.

De la Cruz J., Ramírez P., Bances S., Carbajal W. 2006. Evaluación poblacional del recurso Argopecten purpuratus concha de abanico en la isla Lobos de Tierra (28 abril-02 mayo, 2006). Instituto del Mar del Perú. Technical report. Available at: www. imarpe.pe

Fiestas H., Ormeño U., Castillo J., Acasiete A. 2009. Evaluación de la densidad poblacional de Argopecten purpuratus (Lamarck 1819) en los núcleos y áreas de expansión media del banco natural en la Bahía de Sechura, marzo 2009. Technical report. Available at: www.imarpe.pe

Filun L. 2011. Gametogenic cycle of Mesodesma donacium in Mehuín Beach, Valdivia, Chile-July 1989 to June 1991. Pangaea doi:10.1594/PANGAEA.695910.

Giese A. 1959. Comparative physiology: Annual reproductive cycles of marine invertebrates. Апnи. Rev. Physiol. 21: 547-576.

González M., Pérez M., López D. 2002. Breeding cycle of the northern scallops, Argopecten purpuratus (Lamarck, 1819) in southern Chile. Aquac. Res. 33: 847-852.

Gurney L., Mundy C. 2004. Reproductive biology identifying spawning cycles in the genus Haliotis. Tasmanian Aquaculture and Fishery Institute. Univ. Tasmania, $32 \mathrm{pp}$.

Guzmán N., Marquardt C., Ortlieb L., Frassinetti D. 2000. La malacofauna neogena y cuaternaria del área de Caldera $\left(27^{\circ}-28^{\circ} \mathrm{S}\right)$ : especies y rangos bioestratigráficos. IX Congreso Geológico Chileno. 1: 476-481.

Herrmann M., Alfaya J., Lepore M., Penchaszadeh P., Laudien J. 2009. Reproductive cycle and gonad development of the Northern Argentinean Mesodesma mactroides (Bivalvia: Mesodes- matidae). Helgol. Mar. Res. 63: 207-218.

Illanes J., Akaboshi S., Uribe E. 1985. Efectos de la temperatura en el ostión del norte Chlamys (Argopecten) purpuratus, en la Bahía de Tongoy, durante el fenómeno "El Niño 1982-1983". Invest. Pesq. 32: 167-173.

Jerez G., Aris L., Brown D., Roa R., Miranda H. 2011. Gametogenic cycle of Mesodesma donacium in Longotoma and Peñuelas, Chile, June 1994 to July 1995. Pangaea. DOI: 10.1594/ PANGAEA.695913.

Kang D., Ahn I., Choi K. 2009. The annual reproductive pattern of the Antarctic clam, Laternula elliptica from Marian Cove, King George Island. Polar Biol. 32: 517-528.

Ketata I., Guermazi F., Rebai T., Hamza-Chaffai A. 2007. Variation of steroid concentrations during the reproductive cycle of the clam Ruditapes decussatus: A one year study in the gulf of Gabès area. Comp. Biochem. Physiol. A. 147: 424-431.

Marins L., Levy J. 1999. High genetic distance between marine bivalves of the genus Mesodesma inhabiting the Atlantic and Pacific coasts of South America. Comp. Biochem. Physiol. A 124: 313-319.

Martínez G. 2008. Control de la reproducción y producción de semillas de bivalvos en sistemas controlados. In Lovatelli- Farias A., Uriarte I. (eds.). Estado actual del cultivo y manejo de moluscos bivalvos y su proyección futura: factores que afectan su sustentabilidad en América Latina. FAO Actas de Pesca y Acuicultura. Roma. pp. 267-275.

Montecino V., Lange C. 2009. Eastern Boundary Upwelling Ecosystems: Integrative and Comparative Approaches. Prog. Oceanogr. 83: 65-79.

Oyarzún P., Toro J., Jaramillo R., Guiñez R., Briones C., Astorga M. 2010. Análisis comparativo del ciclo gametogénico de $P e$ rumytilus purpuratus (Bivalvia: Mytilidae), en las localidades de Taltal y Huasco, norte de Chile. Rev. Biol. Mar. Oceanogr. 45: 43-58.

Peredo S., Parada E., Valdebenito I. 1987. Gametogenesis and reproductive cycle of the surf clam Mesodesma donacium (Lamarck, 1818) (Bivalvia: Mesodesmatidae) at Queule Beach, southern Chile. The Veliger 30: 55-68.

Piñones A., Castilla J.C, Guiñez R., Largier J.L. (2007) Nearshore surface temperatures in Antofagasta Bay (Chile) and adjacent upwelling centers. Cienc. Mar. 33: 37-48.

Riascos J.M., Heilmayer O., Laudien J. 2008. Population dynamics of the tropical bivalve Cardita affinis from Málaga Bay, Colombian Pacific related to La Niña 1999-2000. Helgol. Mar. Res. 62: 63-71.

Riascos J.M., Carstensen D., Laudien J., Arntz W., Oliva M. E., Güntner A., Heilmayer O. 2009. Thriving and declining: climate variability shaping life-history and population persistence of Mesodesma donacium in the Humboldt Upwelling System. Mar. Ecol. Prog. Ser. 385: 151-163.

Riascos J.M, Heilmayer O., Oliva M. E., Laudien J. 2011a. Environmental stress and parasitism as drivers of population dynamics of Mesodesma donacium at its northern biogeographic range. ICES J. Mar.Sci. 68: 823-833.

Riascos J.M., Laudien J., Heilmayer O. 2011b. Gametogenic cycle of Mesodesma donacium in Hornitos (II Región) Chile between May 2005 and April 2007. Pangaea doi:10. 1594/ PANGAEA.695933.

Rubilar P., Ariz L., Ojeda V., Lozada E. and others. 2011. Gametogenic cycle of Mesodesma donacium in Cucao and Quilanlar, Chile, September 2000 to August 2001. Pangaea doi:10.1594/ PANGAEA.695934.

Salgado I., Ishiyama V. 2011. Gametogenic cycle of Mesodesma donacium in Camaná, Arequipa, Peru, March 1973 to February 1974. Pangaea doi:10.1594/PANGAEA.695907.

Stead R., Clasing E., Lardies M., Arratia L., Urrutia G., Garrido O. 2002. The significance of contrasting feeding strategies on the reproductive cycle in two coexisting tellinacean bivalves. Mar. Biol. 82: 443-453.

Strub T., Mesías J., Montecino V., Rutland J., Salinas S. 1998. Coastal ocean circulation off western South America. In: Robinson A., Brink K. (eds), The Sea. The Global Coastal Ocean. 11: $273-313$

Taylor M., Wolff M., Vadas F., Yamashiro C. 2008. Trophic and environmental drivers of the Sechura Bay Ecosystem (Peru) over an ENSO cycle. Helgol. Mar. Res. 62: 15-32.

Tarazona J., Espinoza R., Solís M., Wolf A. 2007. Crecimiento y producción somática de la concha de abanico (Argopecten 
purpuratus) en Bahía Independencia, Pisco (Perú) comparados entre eventos El Niño y La Niña. Rev. Biol. Mar. Oceanogr. 42: 275-285.

Tarifeño E. 1980. Studies on the biology of the surf-clam Mesodesma donacium (Lamarck, 1818) (Bivalvia: Mesodesmatidae) from Chilean sandy beaches. $\mathrm{PhD}$ thesis, Univ. California, $228 \mathrm{pp}$.

Thiel M., Macaya E., Acuña E., Arntz W., Bastias H., Brokordt K., Camus P., Castilla J., Castro L., Cortés M., Dumont C., Escribano R., Fernández M., Gajardo J., Gaymer C., Gomez I., González A., González H., Haye P., Illanes J., Iriarte J., Lancellotti D., Luna-Jorquera G., Luxoro C., Manríquez P., Marín V., Muñoz P., Navarrete S., Perez E., Poulin E., Sellanes J., Sepúlveda H., Stotz W., Tala F., Thomas A., Vargas C., Vasquez J., Alonso-Vega J. 2007. The Humboldt Current System of Northern and Central Chile - oceanographic processes, ecological interactions and socioeconomic feedback. Oceanogr. Mar. Biol. Ann. Rev. 45: 195-344.

Urban J. 1994. Upper temperature tolerance of ten bivalve species off Peru and Chile related to El Niño. Mar. Ecol. Prog. Ser. 107: 139-145.

Urban H.J., Tarazona J. 1996. Effects of El Niño/Southern Oscillation on the populations dynamics of a Gari solida population (Bivalvia: Psammobiidae) from Bahía Independencia, Peru.
Mar. Biol. 125:725-734.

Urban J. 2001. Reproductive strategies in tropical bivalves (Pteria colymbus, Pinctada imbricata and Pinna carnea): temporal coupling of gonad production and spat abundance related to environmental variability. J. Shellfish Res. 20. 1127-1134.

Vance R. 1973. On reproductive strategies in marine benthic invertebrates. Am. Nat. 107: 339-352.

von Ihering H. 1907. Les mollusques fossils du tertiaire et du crétace supérieur de l'Argentine. An. Mus. Nac. Ser III 7: 1-611.

Wolff M. 1987. Population dynamics of the Peruvian scallop Argopecten purpuratus during the El Niño phenomenon of 1983. Can. J. Fish. Aquat. Sci. 44: 1684-1691.

Wolff M. 1988. Spawning and recruitment in the Peruvian scallop Argopecten purpuratus. Mar. Ecol. Prog. Ser. 42: 213-217.

Wolff M., Mendo J. 2000. Management of the Peruvian bay scallop (Argopecten purpuratus) metapopulation with regard to environmental change. Aquatic Conserv: Mar. Freshw. Ecosyst. 10: 117-126.

Zar J.H. 1999. Biostatistical analysis. Prentice-Hall, New York, 736 pp.

Scient. ed.: W.E. Arntz.

Received August 2, 2011. Accepted September 14, 2012.

Published online October 26, 2012. 